\title{
Effect of Macrocycle Size on the Self-assembly of Methylimidazolium Surfactant with Sulfonatocalix[n]arenes
}

József G. Harangozó, ${ }^{\text {a }}$ Véronique Wintgens, ${ }^{\text {b }}$ Zsombor Miskolczy, ${ }^{\text {a }}$ Jean-Michel Guigner, ${ }^{\mathrm{c}}$ Catherine Amiel, ${ }^{\mathrm{b}}$ László Biczók ${ }^{\mathrm{a}^{*}}$

${ }^{a}$ Institute of Materials and Environmental Chemistry, Research Centre for Natural Sciences, Hungarian Academy of Sciences, P.O. Box 286, 1519 Budapest, Hungary

${ }^{\mathrm{b}}$ Université Paris Est, ICMPE (UMR7182), CNRS, UPEC, F 94320 Thiais, France

${ }^{\mathrm{c}}$ Institut de Minéralogie, de Physique des Matériaux et de Cosmochimie (IMPMC, Sorbonne Universités - UPMC Université Paris 06, UMR CNRS 7590, Muséum National d'Histoire Naturelle, Institut de Recherche pour le Développement UR 2064 Place Jussieu F-75005 Paris, France

\footnotetext{
* Corresponding author. Phone: (+36 1) 382-6614; E-mail: biczok.laszlo@ttk.mta.hu
} 


\begin{abstract}
The effect of macrocycle size on the association of supramolecular amphiphiles composed of 4-sulfonatocalix[n]arene and 1-methyl-3-tetradecylimidazolium $\left(\mathrm{C}_{14} \mathrm{mim}^{+}\right)$was studied in aqueous solutions at $\mathrm{pH}$ 7. When the cavitand contained four sulfonatophenol units (SCX4), spherical nanoparticle (NP) formation was observed. In contrast, both supramolecular micelle (SM) and NP formation could be attained in the presence of $\mathrm{NaCl}$ when the larger, more flexible 4-sulfonatocalix[8]arene (SCX8) served as host compound. The SCX8-promoted self-assembly into SM was enthalpically more favorable than NP production but the molar heat capacity changes in the two processes barely differed. Addition of $50 \mathrm{mM} \mathrm{NaCl}$ significantly increased the enthalpy of $\mathrm{C}_{14} \mathrm{mim}^{+}-\mathrm{SCX} 8 \mathrm{NP}$ formation making thereby the self-organization into SM more favorable. The transformation of SM into NP at high temperature was due to the substantial entropic contribution to the driving force of NP formation. The critical micelle concentration and the local polarity in the headgroup domain were considerably lower for SM compared to those of $\mathrm{C}_{14} \mathrm{mim}^{+} \mathrm{Br}^{-}$conventional micelle.
\end{abstract}

Key words: Nanoparticle, supramolecular amphiphile, self-assembly, macrocycle, surfactant 


\section{INTRODUCTION}

Complex formation between macrocyclic compounds and surfactants leads to supramolecular amphiphiles, which can associate into various types of nanostructures. ${ }^{1-6}$ Due to the noncovalent binding of the constituents, such associates can be easily prepared with tailor-made properties and stimuli-responsive behavior. $^{7}$ Because of their $\pi$-electron-rich cavity and negative charge, 4-sulfonatocalix[n]arenes (SCXn) are particularly useful building blocks for fabrication of versatile self-assembled systems and functional materials. ${ }^{8-10}$ For example, they induced the aggregation of tetraphenylethene derivatives to strongly fluorescent nanoassemblies ${ }^{11}$ and their emission properties could be tuned by irradiation with UV light. ${ }^{12}$ The binding to SCXn facilitates the aggregation of aromatic or amphiphilic molecules. ${ }^{13-17}$ The interaction of the macrocycle homologue comprised of four sulfonatophenol units (SCX4) with a natural cationic protein, protamine resulted in supramolecular vesicle which disintegrated in a controlled manner upon addition of trypsine. ${ }^{18}$ Enzyme-induced cleavage of vesicles fabricated from SCX4 and myristoylcholine was employed to the release of entrapped drugs. ${ }^{19}$ Supramolecular vesicle constructed from (dodecyloxybenzyl)tripropargylammonium and SCX4 was stabilized by crosslinking with a click reaction. ${ }^{20}$ Serine-based cationic surfactant produced particles of various morphologies upon gradual increase of SCX 4 concentration. ${ }^{21}$ The interaction of this cavitand with chitosan resulted in multistimuli-responsive supramolecular polymeric vesicles which could encapsulate doxorubicine hydrochloride. ${ }^{22}$ High drug loading efficiency was achieved by SCX4promoted self-organization of antipsychotics, chlorpromazine into nanoparticle. ${ }^{23}$ The inclusion complex of the same cavitand with tetradecyltrimethylammonium bromide formed unilamellar vesicle after sonication. ${ }^{24}$ In contrast, supramolecular micelles were spontaneously produced in the solution of dodecyltrimethylammonium $\left(\mathrm{C}_{12} \mathrm{TAB}\right)$ bromide and hexamethylated 4-sulfonatocalix[6]arene $(\mathrm{SC} 6 \mathrm{HM}) .{ }^{25}$ The size and composition of 
supramolecular micelles barely altered upon increase of surfactant concentration up to the critical micelle concentration $(\mathrm{cmc})$ of the free $\mathrm{C}_{12} \mathrm{TAB}$. Above $\mathrm{cmc}, \mathrm{C}_{12} \mathrm{TAB}$ and supramolecular micelles were rapidly merged. ${ }^{26}$

1-Alkyl-3-methylimidazolium $\left(\mathrm{C}_{\mathrm{n}} \mathrm{mim}^{+}\right)$produced host-guest complexes with $\mathrm{SCXn}$ in enthalpy driven reactions. ${ }^{27-29}$ When the alkyl group contained $n=12,14$ or 16 carbon atoms, $\left(\mathrm{C}_{\mathrm{n}} \mathrm{mim}^{+}\right)_{\mathrm{m}}-\mathrm{SCX} 6$ complexes self-assembled to spherical nanoparticles (NPs) of multilayered structure. ${ }^{30}$ NPs composed of $\mathrm{C}_{14} \mathrm{mim}^{+}$and SCX6 constituents showed stimuliresponsive behavior. They reversibly transformed to supramolecular micelles (SM) in the presence of $\mathrm{NaCl}$ when temperature, mixing ratio of the components, or $\mathrm{NaCl}$ concentration were altered. ${ }^{31}$

The present paper focuses on the fundamental question how the variation of the macrocycle size influences the organization of $\mathrm{C}_{14} \mathrm{mim}^{+}$and $\mathrm{SCXn}$ (Scheme 1) into nanostructures under various experimental conditions. We reveal whether stimuli-responsive NP-SM transition can be achieved with SCX4 and SCX8 cavitands and uncover the major factors affecting the thermodynamics of association processes.

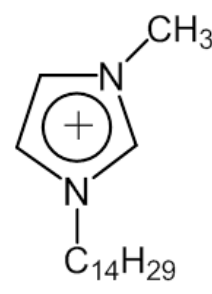

$\mathrm{C}_{14} \mathrm{mim}^{+}$

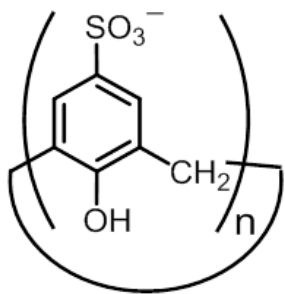

SCXn

Scheme 1. Chemical structure of the studied compounds (SCXn with $n=4,8$ )

\section{EXPERIMENTAL SECTION}

Materials. 1-Methyl-3-tetradecyl-imidazolium bromide $\left(\mathrm{C}_{14} \mathrm{mim}^{+} \mathrm{Br}^{-}\right)$was prepared as described previously. ${ }^{32}$ 4-Sulfonatocalix[4]arene (SCX4) and 4-sulfonatocalix[8]arene (SCX8) (Acros Organics) comprised 1:9 and 1:21 stoichiometric amount of water in its 
crystal structure. ${ }^{33}$ Their solutions were always neutralized by the minimum volume of concentrated $\mathrm{NaOH}$. Double distilled water was used as solvent. 2-Hydroxy-substituted Nile Red (HONR), also called 9-diethylamino-2-hydroxy-5H-benz[a]phenoxazin-5-one (Aldrich) was applied as received.

Sample preparation. Stock solutions of $\mathrm{C}_{14} \mathrm{mim}^{+} \mathrm{Br}^{-}(\sim 2.5 \mathrm{mM})$ and $\mathrm{SCXn}(1 \mathrm{mM}, \mathrm{pH} 7)$ were prepared. NPs were synthesized by mixing the appropriate amounts of these solutions under stirring at $150 \mathrm{rpm}$ at $25^{\circ} \mathrm{C}$. SCXn concentration was $0.1 \mathrm{mM}$ unless otherwise noted. Ionic strength was tuned by addition of small volume $(<50 \mu \mathrm{l})$ of concentrated $\mathrm{NaCl}$ solution. Usage of fluorescent probe. $23 \mathrm{nmol} \mathrm{HONR}$ in methanol was put into $5 \mathrm{ml}$ flask and the solvent was evaporated by nitrogen flow. After adding the supramolecular surfactant solution, the sample was kept for 2 days in the dark for equilibration.

Instrumentation. The absorbances were monitored on an Agilent Technologies Cary60 spectrophotometer. The turbidity values $(\mathrm{T})$ were calculated from the absorbances (A) at 350 $\mathrm{nm}$ by the relationship $\mathrm{T}=1-10^{-\mathrm{A}}$. Corrected fluorescence spectra were obtained on a JobinYvon Fluoromax-P photon-counting spectrofluorometer. Particle size was measured by dynamic light scattering on a Zetasizer Nano-ZS (Malvern Instrument) equipped with a HeNe laser $\left(\lambda=633 \mathrm{~nm}\right.$, scattering angle $\left.173^{\circ}\right) .12$ runs of 10 seconds were averaged. Data were analyzed with the software developed by the manufacturer using a distribution analysis (General Purpose analysis). The mean diameter of the NPs was derived on the basis of number distribution. Experiments were repeated at least twice. NPs were separated from the liquid phase by a Beckman Coulter (Optima Max-XP, type TLA 110 rotor) ultracentrifuge. Total carbon analyses were carried out on a Shimadzu TOC-L CSN instrument, which was calibrated by a potassium hydrogen phthalate solution in ultrapure water $\left(2.125 \mathrm{~g} \mathrm{dm}^{-3}\right.$ corresponding to $1000 \mathrm{mgC} \mathrm{dm}^{-3}$ ). ITC measurements were executed with a MicroCal VPITC microcalorimeter. $10 \mu \mathrm{l}$ of $\sim 5 \mathrm{mM}$ methylimidazolium surfactant solutions were injected 
from the computer controlled microsyringe into the cell (volume $=1.4569 \mathrm{ml})$ containing 0.1 mM SCXn solution at $\mathrm{pH} 7$, while stirring at $450 \mathrm{rpm}$. Cryo-TEM images were taken on an Ultrascan 2 k CCD camera (Gatan, USA), using a LaB 6 JEOL JEM 2100 (JEOL, Japan) cryo-microscope operating at $200 \mathrm{kV}$ with a JEOL low dose system (Minimum Dose System, MDS) to protect the thin ice film from any irradiation before imaging and to reduce the irradiation during the image capture. The images were taken at $93 \mathrm{~K}$ and digitally corrected using the ImageJ software. The samples were prepared as described. ${ }^{31}$

\section{RESULTS}

Association of SCX4 with $\mathbf{C}_{\mathbf{1 4}} \mathbf{m i m}^{+}$. NP formation was observed when $\mathrm{C}_{14} \mathrm{mim}^{+}$and neutralized solution of $0.1 \mathrm{mM} \mathrm{SCX} 4$ were mixed in $1.0-4.6$ molar ratios at $298 \mathrm{~K}$. (Scheme 2)
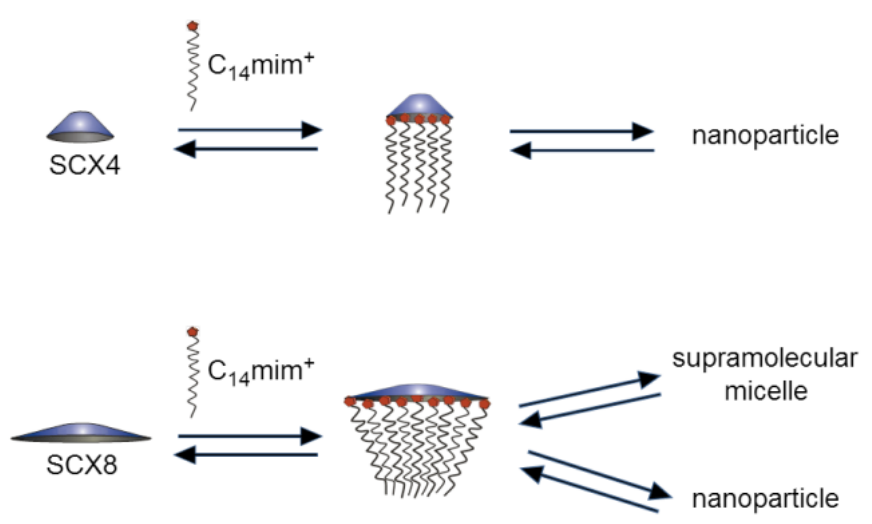

Scheme 2 Illustration of nanoparticle and supramolecular micelle formation

After mixing, the NP diameter increases with the molar ratio from 71 to $105 \mathrm{~nm}$. The size of NPs initially grew over the first hours. Therefore, all measurements were performed after 3 hours and the mean diameters were between 200 and $300 \mathrm{~nm}$. At $\left[\mathrm{C}_{14} \mathrm{mim}^{+}\right] /[\mathrm{SCX} 4] \approx 5$, coagulation took place because of charge compensation between methylimidazolium surfactant cations and the negatively charged macrocycle. In neutral solution, not only the 4 sulfonate groups were deprotonated but also one phenolic $\mathrm{OH}$ substituent of SCX4 
dissociated due to its $\mathrm{pK}_{\mathrm{a}}=3.2$ value. ${ }^{34}$ Hence, SCX4 had 5 negative charges at $\mathrm{pH} 7$. From the difference between the total concentrations and the concentrations in the aqueous phase after ultracentrifugation of the NPs, the stoichiometry of the components in NPs was determined. ${ }^{30} \mathrm{C}_{14} \mathrm{mim}^{+}$:SCX4 molar ratio in NPs was found to be $4.6 \pm 0.4$ for a mixing ratio of 2.5. NPs had negative charge and the zeta potential was around $-37 \pm 3 \mathrm{mV}$ for mixing ratio varying between 2 and 4. Figure 1 displays that the gradual increase of $\mathrm{NaCl}$ concentration barely influences the turbidity of the solution and the diameter of NPs at $\left[\mathrm{C}_{14} \mathrm{mim}^{+}\right] /[\mathrm{SCX} 4]=2$ and 4 alike. This is in a sharp contrast to the marked $\mathrm{NaCl}$ effect on the characteristics of $\mathrm{C}_{14} \mathrm{mim}^{+}-\mathrm{SCX} 6 \mathrm{NPs}$, whose size grew with $\mathrm{NaCl}$ concentration and reassembly of the NP components into supramolecular micelles (SM) was observed around

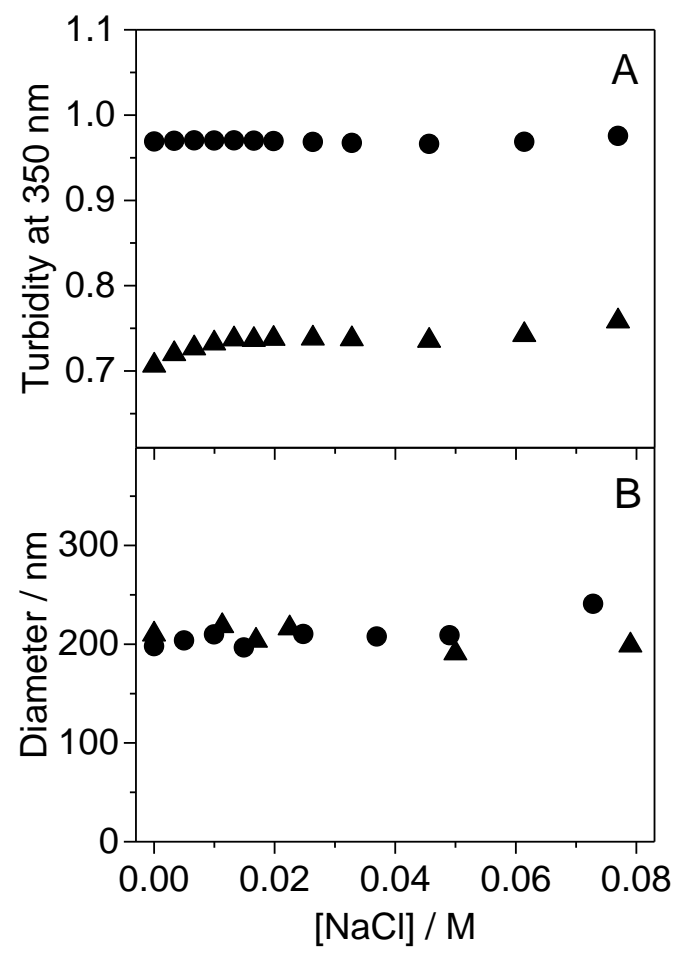

Figure 1. Effect of $\mathrm{NaCl}$ concentration on (A) turbidity at $350 \mathrm{~nm}$ for $\mathrm{C}_{14} \mathrm{mim}^{+}: \mathrm{SCX} 4$ solution of molar ratio $2(\boldsymbol{\Delta})$ and $4(\bullet)$. (B) Mean particle diameter as a function of $\mathrm{NaCl}$ concentration for $\mathrm{C}_{14} \mathrm{mim}^{+}: \mathrm{SCX} 4$ solution of molar ratio $2(\boldsymbol{\Delta})$ and $4(\bullet)$. The mixture of $\mathrm{C}_{14} \mathrm{mim}^{+}$and $\mathrm{SCX} 4$ solution was equilibrated for 3 hours before successive $\mathrm{NaCl}$ additions at $298 \mathrm{~K} .[\mathrm{SCX} 4]=0.1 \mathrm{mM}$ 
40, 25, and $15 \mathrm{mM} \mathrm{NaCl}$ concentration in the case of $\left[\mathrm{C}_{14} \mathrm{mim}^{+}\right] /[\mathrm{SCX} 6]=4,3$, and 2 , respectively. ${ }^{31}$ In the case of the smaller SCX4 cavitand, neither $\mathrm{NaCl}$ addition nor temperature variation could induce the transformation of NP into SM. This may suggests that the driving force of NP production is always more favorable than that of association to SM. As a representative example, Figure 2A presents a cryo-TEM image of NPs synthesized in the solution of $0.25 \mathrm{mM} \mathrm{C}_{14} \mathrm{mim}^{+} \mathrm{Br}^{-}$and $0.1 \mathrm{mM} \mathrm{SCX} 4$ at $\mathrm{pH} 7$. Homogeneous and spherical NPs are observed.

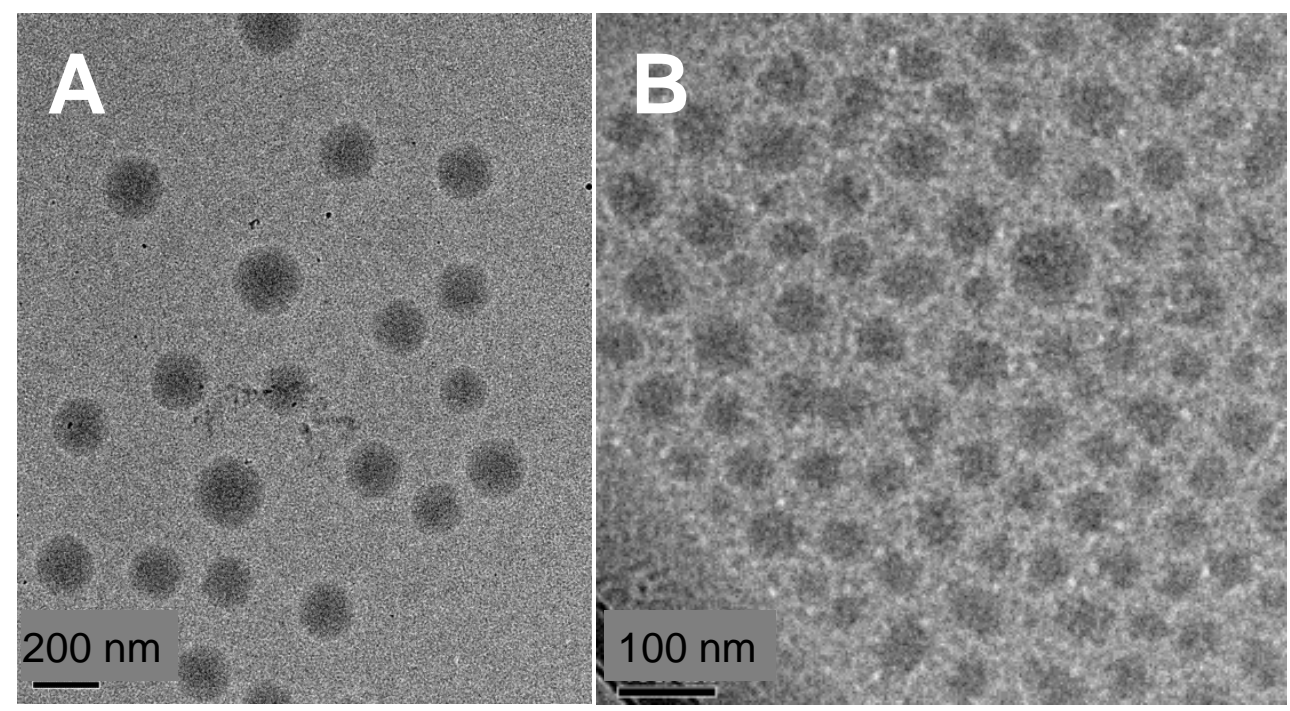

Figure 2 Cryo-TEM images for $(\mathrm{A}) \mathrm{C}_{14} \mathrm{mim}^{+}-\mathrm{SCX} 4$ NPs prepared at $\left[\mathrm{C}_{14} \mathrm{mim}^{+}\right] /[\mathrm{SCX} 4]=$ 2.5 molar ratio $[\mathrm{SCX} 4]=0.1 \mathrm{mM}$ and $(\mathrm{B}) \mathrm{C}_{14} \mathrm{mim}^{+}-\mathrm{SCX} 8$ NPs obtained at $\left[\mathrm{C}_{14} \mathrm{mim}^{+}\right] /[\mathrm{SCX} 8]=6$ molar ratio $[\mathrm{SCX} 8]=0.1 \mathrm{mM}$.

Self-assembly of SCX8 with $\mathbf{C}_{\mathbf{1 4}} \mathbf{m i m}^{+}$. In contrast to the size increase of $\mathrm{C}_{14} \mathrm{mim}^{+}-\mathrm{SCX} 4$ NPs over time, stable NPs were rapidly produced when SCX4 was replaced by the larger more flexible SCX8 macrocycle. Turbidity enhancement and growth of the NP diameter is observed with the molar ratio increase (Figure 3). NPs were much smaller than in the case of SCX4 and coagulation occurred around $\left[\mathrm{C}_{14} \mathrm{mim}^{+}\right] /[\mathrm{SCX} 8]=10$ because $\mathrm{SCX} 8$ had 10 negative charge at $\mathrm{pH} 7$. In addition to the 8 anionic sulfonate moieties, 2 phenolate groups 


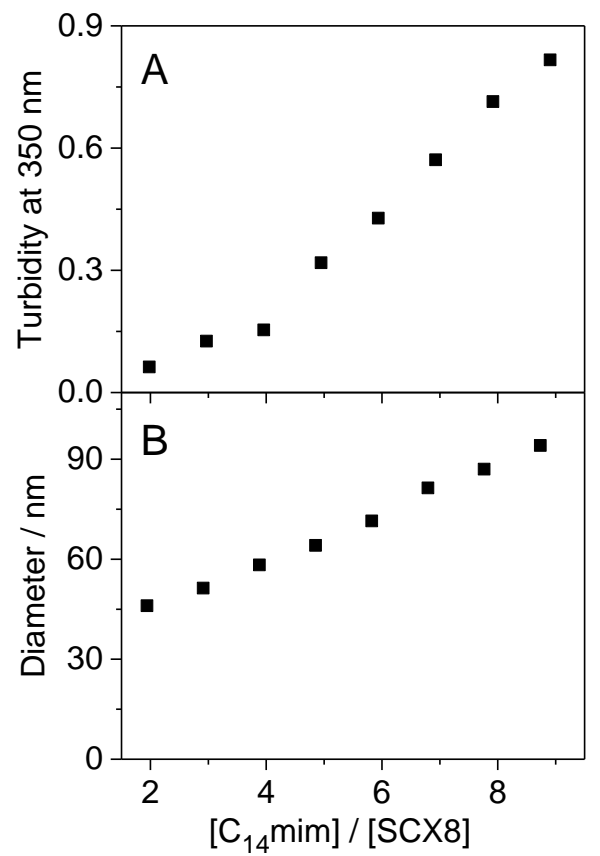

Figure 3. Alteration of (A) turbidity at $350 \mathrm{~nm}$ and (B) NP diameter as a function of $\mathrm{C}_{14} \mathrm{mim}^{+}: \mathrm{SCX} 8$ molar ratio in neutral aqueous solution at $298 \mathrm{~K}[\mathrm{SCX} 8]=0.1 \mathrm{mM}$. No diameter change was observed in 2 hours.

appear because the phenolic units of SCX8 have $\mathrm{pK}_{\mathrm{a}}$ values ${ }^{34}$ of 3.0 and 4.4. To some extent the third phenolic $\mathrm{OH}$ also starts deprotonation due to $\mathrm{pK}_{\mathrm{a}}=8.3$ value of this process. ${ }^{34}$ From the difference between the total concentration and aqueous phase concentration after ultracentrifugation of the NPs, a value of $9.5 \pm 0.5$ was obtained for the $\mathrm{C}_{14} \mathrm{mim}^{+}: \mathrm{SCX} 8$ stoichiometry of the components in NPs formed from solutions at 3.9, 5.8, and 6.8 mixing ratios. Despite the rise of the relative amount of $\mathrm{C}_{14} \mathrm{mim}^{+}$added to SCX8 solution, the molar ratio of the constituents in the produced NPs remains constant within the limits of experimental errors. NPs had negative charge as indicated by the zeta potential $(\zeta)$ of $-48 \pm 4$ $\mathrm{mV}$, which did not vary within the mixing ratio range of the components used in our studies. Figure 2B presents a representative cryo-TEM image of NPs synthesized in the solution of 0.6 $\mathrm{mM} \mathrm{C}_{14} \mathrm{mim}^{+} \mathrm{Br}^{-}$and $0.1 \mathrm{mM} \mathrm{SCX} 8$ at $\mathrm{pH} 7$. As for $\mathrm{C}_{14} \mathrm{mim}^{+}-\mathrm{SCX} 4 \mathrm{NPs}$, the observed NPs have spherical and homogeneous structure. 


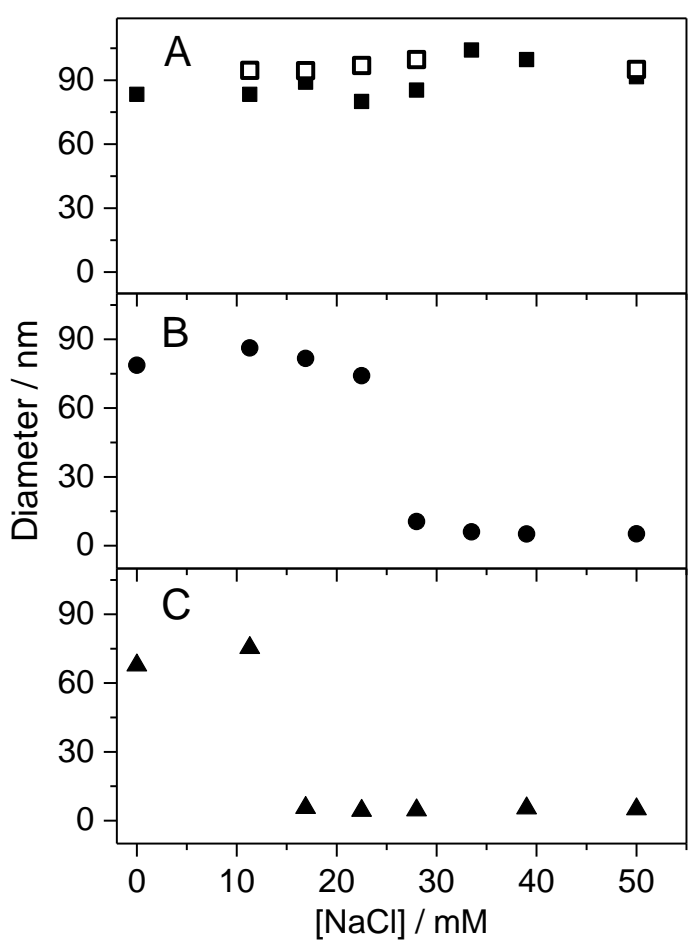

Figure 4. Particle diameter change with $\mathrm{NaCl}$ concentration at solution mixing ratios (A) $\left[\mathrm{C}_{14} \mathrm{mim}^{+}\right] /[\mathrm{SCX} 8]=8.8(\square), 6.8(\bullet),(\mathrm{B}) 5.8(\bullet)$, and (C) $3.9(\boldsymbol{\Delta})$ at $298 \mathrm{~K}$. [SCX8] was kept constant $0.1 \mathrm{mM}$. Measurements were performed immediately after each successive $\mathrm{NaCl}$ addition.

In contrast, successive $\mathrm{NaCl}$ addition exerted remarkable effect on particle size as displayed in Figure 4. NP dimensions barely changed with $\mathrm{NaCl}$ concentration in $6.8<$ $\left[\mathrm{C}_{14} \mathrm{mim}^{+}\right] /[\mathrm{SCX} 8]<8.8$ range. Less than $10 \%$ change was found in $\zeta$ values when $\mathrm{NaCl}$ concentration was raised to $50 \mathrm{mM}$ at mixing ratio of $\left[\mathrm{C}_{14} \mathrm{mim}^{+}\right] /[\mathrm{SCX} 8]=7.8$, (under this condition $\zeta=-44.1 \mathrm{mV}$ and $-43.1 \mathrm{mV}$ were determined at $\mathrm{NaCl}$ concentrations of 0 and 50 $\mathrm{mM}$, respectively), whereas $\mathrm{NaCl}$ addition induced supramolecular micelle (SM) formation at lower $\left[\mathrm{C}_{14} \mathrm{mim}^{+}\right] /[\mathrm{SCX} 8]$ ratios. To avoid conventional micelle formation, $\mathrm{C}_{14} \mathrm{mim}^{+}$ concentration was below the critical micelle concentration, which is $2.5 \mathrm{mM}$ in water ${ }^{32}$ and $0.72 \mathrm{mM}$ in $50 \mathrm{mM} \mathrm{NaCl}$ aqueous solution. The latter value was determined by isothermal calorimetric titrations as described by Blume and coworkers. ${ }^{35}$ The diameter of SM was $5.0 \pm$ 
$0.5 \mathrm{~nm}$ regardless of salt concentration. As seen in Figure 4, the amount of $\mathrm{NaCl}$ required for the NP transformation to $\mathrm{SM}$ diminished with lowering $\left[\mathrm{C}_{14} \mathrm{mim}^{+}\right] /[\mathrm{SCX} 8]$ ratio but $\mathrm{SM}$ was not produced in the absence of salt. At $\left[\mathrm{C}_{14} \mathrm{mim}^{+}\right] /[\mathrm{SCX} 8]=4.9, \mathrm{SM}$ was stable up to 318 and $323 \mathrm{~K}$ in the presence of 30 and $50 \mathrm{mM} \mathrm{NaCl}$, respectively (Figure $\mathrm{S} 1$ in Supporting Information). Particles, characterized by polydispersity index of $\sim 0.45$ and mean diameter $>$ $400 \mathrm{~nm}$, were obtained at higher temperatures.

Isothermal Titration Calorimetry (ITC). To gain a deeper understanding of the factors controlling the thermodynamics of association processes, ITC experiments were performed at various temperatures. Enthalpograms corrected by the dilution heat of $\mathrm{C}_{14} \mathrm{mim}^{+}$are presented in Figure $\mathrm{S} 2$ in Supporting Information for the titration of $0.1 \mathrm{mM} \mathrm{SCX} 4$ by $2.9 \mathrm{mM} \mathrm{C}_{14} \mathrm{mim}^{+}$ in neutral aqueous solution. The $\Delta \mathrm{H}$ values in the $0.5<\left[\mathrm{C}_{14} \mathrm{mim}^{+}\right] /[\mathrm{SCX} 4]<4.3$ domain are attributed to NP formation, which occurs in several steps. The 1:1 complexation is followed by multiple binding of $\mathrm{C}_{14} \mathrm{mim}^{+}$facilitated by the 5 negative charges of SCX4 and hydrophobic interactions. Then, self-assembly into NPs takes place. $\Delta \mathrm{H}$ of NP production is an overall quantity containing the contributions of various association steps. Dynamic light scattering measurements immediately after mixing the components show the growth of the mean NP diameter from 71 to $105 \mathrm{~nm}$ in the $0.5<\left[\mathrm{C}_{14} \mathrm{mim}^{+}\right] /[\mathrm{SCX} 4]<4.3$ domain. The small $\Delta \mathrm{H}$ increase in this molar ratio range with the relative amount of methylimidazolium surfactant may imply the slightly lower exothermicity of the assembly into larger NPs. The substantial $\Delta \mathrm{H}$ change in the $4.3-5.0\left[\mathrm{C}_{14} \mathrm{mim}^{+}\right] /[\mathrm{SCX} 4]$ range is due to the onset of coagulation.

Similar enthalpograms are measured in the presence of $50 \mathrm{mM} \mathrm{NaCl}$ (Figure 5A). NPs are produced in a slightly endothermic process at $278 \mathrm{~K}$, whereas association to NP is accompanied by heat evolution above $278 \mathrm{~K}$. Figure $6 \mathrm{~A}$ presents the linear correlations 

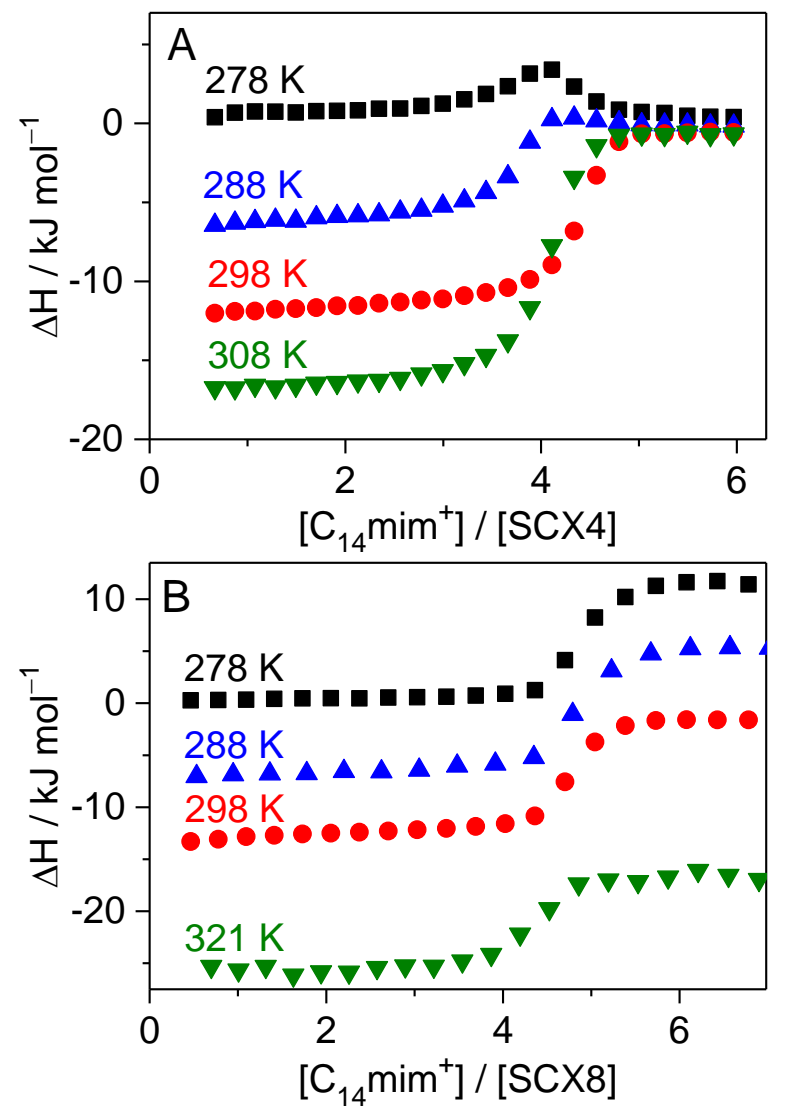

Figure 5 Results of ITC experiments at various temperatures in $50 \mathrm{mM} \mathrm{NaCl}$ solutions after correction with dilution heat. (A) NP formation upon the titration of SCX4 with $\mathrm{C}_{14} \mathrm{mim}^{+}$; (B) self-assembly into SM and NP upon addition of $\mathrm{C}_{14} \mathrm{mim}^{+}$to SCX8

between $\Delta \mathrm{H}$ and temperature $(\mathrm{T})$ whose slopes give the molar heat capacity changes $\left(\Delta \mathrm{C}_{\mathrm{p}}\right)$. The isoenthalpic temperatures $\left(\mathrm{T}_{\mathrm{ie}}\right)$, where association takes place without enthalpy change, were calculated as a ratio of the intercept and $-\Delta C_{p}$ values. As seen in Table 1 and Figure 6A, the intercepts of $\Delta \mathrm{H}$ vs $\mathrm{T}$ plots for $\mathrm{C}_{14} \mathrm{mim}^{+}-\mathrm{SCX} 4 \mathrm{NP}$ formation are slightly reduced, whereas $\Delta \mathrm{C}_{\mathrm{p}}$ values becomes somewhat less negative upon addition of $50 \mathrm{mM} \mathrm{NaCl}$ concentration. Consequently, association into NP becomes exothermic at lower temperature in $\mathrm{NaCl}$ solution than in water.

Figure S3 in Supporting Information presents the results of ITC experiments for the titration of $0.1 \mathrm{mM} \mathrm{SCX8}$ aqueous solution with $5.54 \mathrm{mM} \mathrm{C}_{14} \mathrm{mim}^{+}$. The enthalpograms 


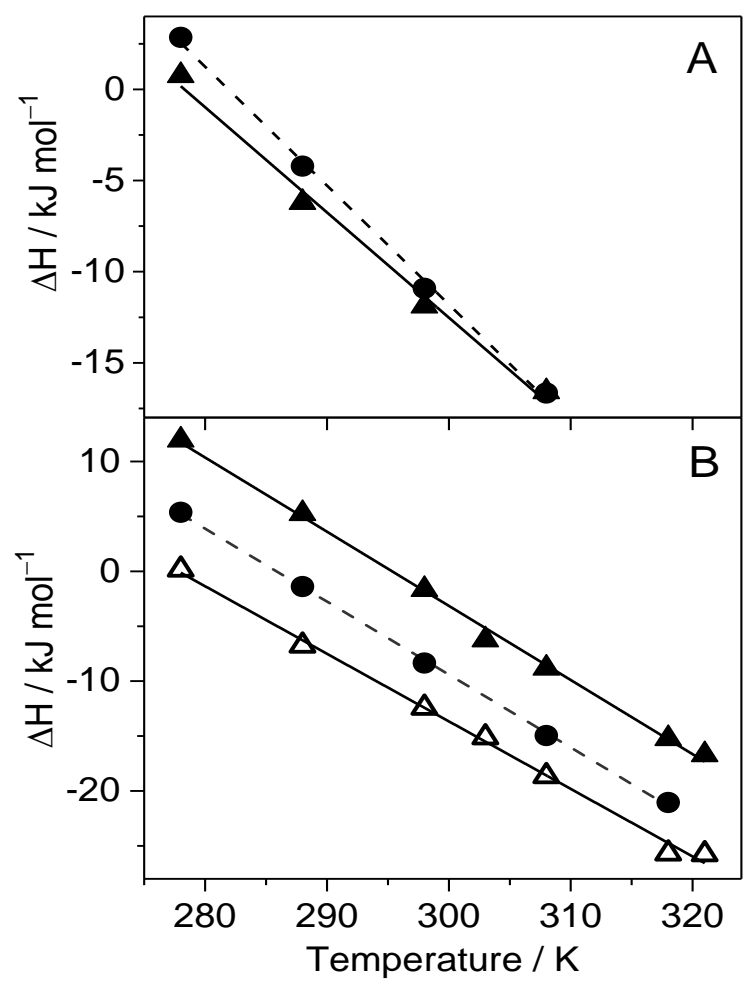

Figure 6 Enthalpy change per mole of methylimidazolium surfactant as a function of temperature (A) for $\mathrm{C}_{14} \mathrm{mim}^{+}-\mathrm{SCX} 4 \mathrm{NP}$ formation in $50 \mathrm{mM} \mathrm{NaCl}$ aqueous solution $(\boldsymbol{\Delta})$ and water (•); (B) for the association of $\mathrm{C}_{14} \mathrm{mim}^{+}$and SCX8 into SM ( ), a $\Delta \mathbf{v} \mathrm{NP}(\boldsymbol{\Delta})$ in $50 \mathrm{mM}$ $\mathrm{NaCl}$ aqueous solutions, and for NP formation in water $(\bullet)$

closely resemble that obtained with SCX4 (Figure S2) indicating NP formation without transformation to SM. The only remarkable difference is that $\Delta \mathrm{H}$ increase due to coagulation starts at higher methylimidazolium surfactant/calixarene ratio, as also observed by DLS experiments (vide supra). In the presence of $\mathrm{NaCl}$, ITC experiments confirm the conversion of SM into NP upon further addition of methylimidazolium surfactant. Figure 5B presents the results in $50 \mathrm{mM} \mathrm{NaCl}$ solutions. Surprisingly, the $\mathrm{C}_{14} \mathrm{mim}^{+}: \mathrm{SCX} 8$ molar ratio at which SM-NP transition occurs scarcely alters upon the elevation of temperature. This suggests that the thermodynamic parameters of the self-assembly to SM and NP have similar temperature dependence. Figure $6 \mathrm{~B}$ displays the variation of $\Delta \mathrm{H}$ values upon rise of temperature, whereas 
Table 1 Parameters of the temperature dependence of enthalpy changes

\begin{tabular}{|c|c|c|c|c|c|c|}
\hline particle & SCXn & $\begin{array}{c}\mathrm{NaCl} / \\
\mathrm{mM}\end{array}$ & $\begin{array}{c}\Delta \mathrm{H}(298 \mathrm{~K}) / \\
\mathrm{kJ} \mathrm{mol}^{-1}\end{array}$ & $\begin{array}{c}\Delta \mathrm{C}_{\mathrm{p}} / \\
\mathrm{kJ} \mathrm{mol}^{-1} \mathrm{~K}^{-1}\end{array}$ & $\begin{array}{l}\text { Intercept / } \\
\mathrm{kJ} \mathrm{mol}^{-1}\end{array}$ & $\begin{array}{c}\text { Isoenthalpic } \\
\text { temperature / K }\end{array}$ \\
\hline $\begin{array}{c}\mathrm{C}_{14} \mathrm{mim}^{+} \mathrm{Cl}^{-} \\
\text {micelle }^{\mathrm{a}}\end{array}$ & - & 0 & - & $-0.595^{\mathrm{a}}$ & - & \\
\hline $\begin{array}{l}\mathrm{C}_{14} \mathrm{mim}^{+} \mathrm{Br}^{-} \\
\text {micelle }\end{array}$ & - & 50 & -2.0 & -0.54 & 160 & 296 \\
\hline \multirow{3}{*}{ SM } & SCX4 & 50 & $\mathrm{~b}$ & $\mathrm{~b}$ & $\mathrm{~b}$ & $\mathrm{~b}$ \\
\hline & SCX6 & 50 & $-17.0^{\mathrm{c}}$ & $-0.59^{\mathrm{c}}$ & $159^{c}$ & $269^{c}$ \\
\hline & SCX8 & 50 & -12.3 & -0.64 & 178 & 278 \\
\hline \multirow{6}{*}{ NP } & \multirow{2}{*}{ SCX4 } & 0 & -10.9 & -0.65 & 184 & 283 \\
\hline & & 50 & -11.9 & -0.58 & 161 & 279 \\
\hline & \multirow{2}{*}{$\mathrm{SCX}^{\mathrm{c}}$} & 0 & $-10.8^{\mathrm{c}}$ & $-0.64^{\mathrm{c}}$ & $182^{c}$ & $284^{\mathrm{c}}$ \\
\hline & & 50 & $-2.3^{c}$ & $-1.44^{\mathrm{c}}$ & $428^{c}$ & $297^{c}$ \\
\hline & \multirow{2}{*}{ SCX8 } & 0 & -8.4 & -0.66 & 189 & 286 \\
\hline & & 50 & -1.5 & -0.68 & 201 & 296 \\
\hline
\end{tabular}

${ }^{\mathrm{a}}$ Ref. $^{36},{ }^{\mathrm{b}} \mathrm{SM}$ is not produced, ${ }^{\mathrm{c}}$ Ref. ${ }^{31}$

the molar heat capacity changes $\left(\Delta \mathrm{C}_{\mathrm{p}}\right)$ derived from the slopes are summarized in Table 1 . The isoenthalpic temperature $\left(\mathrm{T}_{\mathrm{ie}}\right)$, where association takes place without enthalpy change $(\Delta \mathrm{H}=0)$ is also included. $\mathrm{T}_{\mathrm{ie}}$ of SCX6-induced SM formation is below of the freezing point of the solution implying that this process is always exothermic. In contrast, $\mathrm{C}_{14} \mathrm{mim}^{+}-\mathrm{SCX} 8 \mathrm{SM}$ is produced in an entropy-driven process below $278 \mathrm{~K}$. Addition of $50 \mathrm{mM} \mathrm{NaCl}$ lowers $\mathrm{T}_{\mathrm{ie}}$ for $\mathrm{C}_{14} \mathrm{mim}^{+}-\mathrm{SCX} 4 \mathrm{NPs}$, but exerts opposite effect when SCX4 is replaced by more spacious homologues. In water, $\mathrm{T}_{\mathrm{ie}}$ of NP formation slightly increases with the macrocycle size. In 50 $\mathrm{mM} \mathrm{NaCl}$ solution, SM formation always leads to lower $\Delta \mathrm{H}$ than self-organization into NP. The latter process becomes enthalpically more favorable in the absence of salt. $\Delta C_{p}$ values barely differ. Addition of $50 \mathrm{mM} \mathrm{NaCl}$ does not alter $\Delta \mathrm{H}$ values of $\mathrm{SM}$ production and their temperature dependence. Since SM formation is always more exothermic than association 
into NP, the SM transformation to NP found at $\left[\mathrm{C}_{14} \mathrm{mim}^{+}\right] /[\mathrm{SCX} 8]=4.9$ in $50 \mathrm{mM} \mathrm{NaCl}$ solution when the temperature was elevated from 318 to $328 \mathrm{~K}$ is probably due to the substantial increase of favorable entropy contribution to the driving force of NP formation (vide supra).

Critical Aggregation Concentration of Supramolecular Surfactant. 2-Hydroxysubstituted Nile Red (HONR, Scheme 2) fluorescent probe was used for the determination of critical aggregation concentration (cac) of SM at $296 \mathrm{~K}$. This dye is barely soluble in water<smiles>CN(C)c1ccc2nc3c4cc(O)ccc4c(=O)cc-3oc2c1</smiles>

HONR

Scheme 2 Chemical structure of 2-hydroxy-substituted Nile Red fluorescent probe

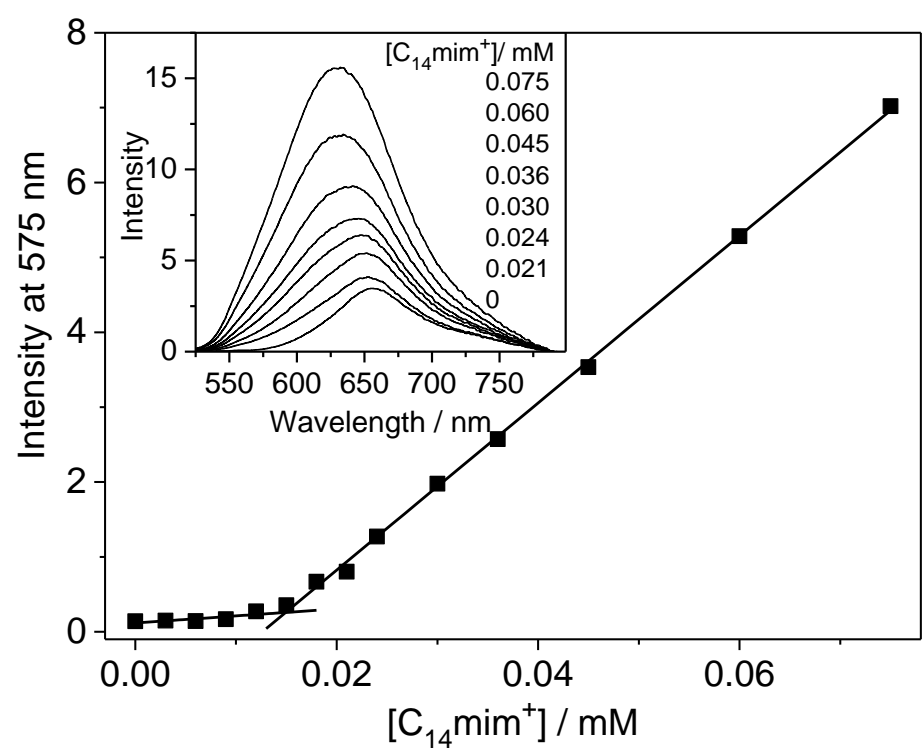

Figure 7 Fluorescence intensity and fluorescence spectra (inset) for saturated HONR solution as a function of $\mathrm{C}_{14} \mathrm{mim}^{+}$concentration in the presence of $\mathrm{SCX} 8$ and $50 \mathrm{mM} \mathrm{NaCl}$ at $\mathrm{pH} 7$ and $296 \mathrm{~K} .\left[\mathrm{C}_{14} \mathrm{mim}^{+}\right] /[\mathrm{SCX} 8]=2$; excitation at $510 \mathrm{~nm}$ 
and SCXn aqueous solutions but readily solubilized in the Stern layer of micelles. ${ }^{37}$ As a representative example, Figure 7 presents the alteration of the HONR fluorescence characteristics upon synchronous increase of $\mathrm{C}_{14} \mathrm{mim}^{+}$and SCX8 concentrations keeping their molar ratio of 2 constant in $50 \mathrm{mM} \mathrm{NaCl}$ solution. Similar results measured at $\left[\mathrm{C}_{14} \mathrm{mim}^{+}\right] /[\mathrm{SCX} 8]=5.9$ molar ratios in $50 \mathrm{mM} \mathrm{NaCl}$ are displayed in Figure $\mathrm{S} 4$ in Supporting Information. The fluorescence intensity is low and constant up to $0.015 \mathrm{mM}$ $\mathrm{C}_{14} \mathrm{mim}^{+}$concentration, whereas considerable hypsochromic shift of the fluorescence maximum and intensity growth are observed above this concentration. The sharp break in the plot arises from the onset of association. ${ }^{32}$ No fluorescence intensity enhancement occurs in SCX8 solution. As the number of SMs increases, more HONR can be confined and consequently, the fluorescence intensity gradually rises. From the intersection of the two linear parts of fluorescence intensity change at $510 \mathrm{~nm}$, cac values of 0.015 and $0.012 \mathrm{mM}$

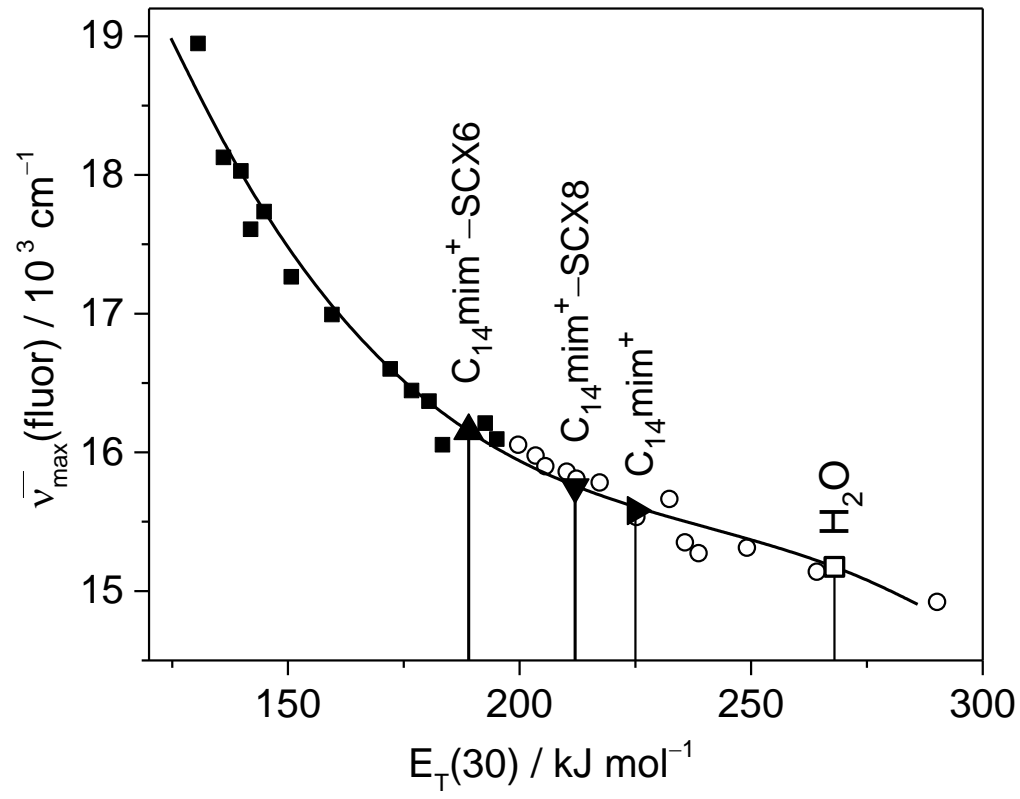

Figure 8 Shift of fluorescence maximum of HONR with increasing $\mathrm{E}_{\mathrm{T}}(30)$ solvent polarity parameter in water $(\square)$, aprotic ( $\square)$ and hydroxylic (O) solvents. The local polarity of HONR in $\mathrm{C}_{14} \mathrm{mim}^{+}$conventional micelle $(\boldsymbol{\nabla}), \mathrm{C}_{14} \mathrm{mim}^{+}-\mathrm{SCX} 6(\boldsymbol{\Delta})$ and $\mathrm{C}_{14} \mathrm{mim}^{+}-\mathrm{SCX} 8(\boldsymbol{\nabla})$ supramolecular micelles in $50 \mathrm{mM} \mathrm{NaCl}$ solution 
$\mathrm{C}_{14} \mathrm{mim}^{+}$are obtained at $\left[\mathrm{C}_{14} \mathrm{mim}^{+}\right] /[\mathrm{SCX} 8]=2.0$ and 5.9 molar ratios in $50 \mathrm{mM} \mathrm{NaCl}$, respectively. The variation of the $\left[\mathrm{C}_{14} \mathrm{mim}^{+}\right] /[\mathrm{SCX} 8]$ ratio scarcely affects cac. In a control experiment, $0.72 \mathrm{mM}$ was found for the $\mathrm{cmc}$ of $\mathrm{C}_{14} \mathrm{mim}^{+} \mathrm{Br}^{-}$in $50 \mathrm{mM} \mathrm{NaCl}$ aqueous solution.

Figure 8 displays the remarkable displacement of the fluorescence maximum of HONR as a function of $\mathrm{E}_{\mathrm{T}}(30)$ polarity parameter of various solvents. ${ }^{37-38}$ Using this relationship, the local polarity around the probe can be determined from the fluorescence maximum of micelle-bound dye. The surroundings of HONR close to the interfacial layer of $\mathrm{C}_{14} \mathrm{mim}^{+}-\mathrm{SCX} 8 \mathrm{SM}$ have significantly higher polarity $\left(\mathrm{E}_{\mathrm{T}}(30)=212 \mathrm{~kJ} \mathrm{~mol}^{-1}\right)$ than in $\mathrm{C}_{14} \mathrm{mim}^{+}-\mathrm{SCX} 6 \mathrm{SM}\left(\mathrm{E}_{\mathrm{T}}(30)=189 \mathrm{~kJ} \mathrm{~mol}^{-1}\right)$, but its polarity is lower than in $\mathrm{C}_{14} \mathrm{mim}^{+}$ conventional micelle $\left(\mathrm{E}_{\mathrm{T}}(30)=225 \mathrm{~kJ} \mathrm{~mol}^{-1}\right)$. SCXn binds to the cationic moiety of methylimidazolium.$^{27}$ The interaction with the apolar methylene-linked aromatic moieties of the macrocycle lessens the local polarity in the vicinity of the headgroup of $\mathrm{C}_{14} \mathrm{mim}^{+}$. The looser fit of the confined methylimidazolium group in the more spacious SCX8 renders the head group region of $\mathrm{C}_{14} \mathrm{mim}^{+}-\mathrm{SCX} 8 \mathrm{SM}$ more hydrated than in the case of $\mathrm{C}_{14} \mathrm{mim}^{+}-\mathrm{SCX} 6$ SM.

\section{DISCUSSION}

The variation of macrocycle size brings about essential differences in the SCXn-induced selfassembly of $\mathrm{C}_{14} \mathrm{mim}^{+}$. The small SCX4 cavitand induces only NP formation, whereas association of $\mathrm{C}_{14} \mathrm{mim}^{+}-\mathrm{SCX} 8$ supramolecular amphiphiles can result in both NP and SM depending on the experimental conditions. Since the macrocycle is located in the headgroup of $\mathrm{C}_{14} \mathrm{mim}^{+}-\mathrm{SCXn}$ type of supramolecular surfactants, the replacement of SCX8 with SCX4 renders the assembly into SM less favorable due partly to steric reason. Israelachvili and coworkers defined a critical packing parameter as $p=V /(A l)$, where $V$ denotes the surfactant 
tail volume, $A$ stands for the cross-sectional area per molecule at the aggregate surface, and $l$ is the length of the hydrophobic moiety of the surfactant. ${ }^{39}$ According to their geometric packing theory, spherical micelles are obtained when the critical packing parameter is below $1 / 3$, whereas planar bilayers are produced when $p \approx 1$. The cross sectional area of SCXn can be approximated by $n$-sided regular convex polygons possessing side length $s$, where $n$ corresponds to the number of repeat units in SCXn and $s$ does not change for various SCXn macrocycles because the size of repeat units remains constant. The area $A$ of a convex regular n-sided polygon is given as follows:

$$
A=\frac{n}{4} s^{2} \cot \frac{\pi}{n}
$$

On the basis of eq 1, the area ratio for a regular octagon and a square is

$$
\frac{A_{8}}{A_{4}}=\frac{2 \cot \frac{\pi}{8}}{\cot \frac{\pi}{4}}=\frac{2(1+\sqrt{2})}{1} \approx 4.83
$$

When only geometric constrains are considered, the lessening of the macrocycle size from SCX8 to SCX4 has two consequences, assuming that the building blocks are constituted of one SCXn neutralized by $\mathrm{m} \mathrm{C}_{14} \mathrm{mim}^{+}$. (i) The cross-sectional area per $\left(\mathrm{C}_{14} \mathrm{mim}^{+}\right)_{\mathrm{m}}-\mathrm{SCXn}$ units of SM decreases by a factor of $\approx 4.83$ and (ii) $V$ diminishes by a factor of $\sim 2$ because the number of $\mathrm{C}_{14} \mathrm{mim}^{+}$cations bound to SCX4 should be about half of that confined to SCX8. Because of these effects V/A becomes significantly larger for $\mathrm{C}_{14} \mathrm{mim}^{+}-\mathrm{SCX} 4$ aggregates. Since the alkyl chain is not varied, $l$ is a constant, and growth of $p=V /(A l)$ is anticipated when SCX8 is replaced with SCX4 in aggregates. Consequently, the morphology of aggregates should be different between $\mathrm{C}_{14} \mathrm{mim}^{+}-\mathrm{SCX} 4$ and $\mathrm{C}_{14} \mathrm{mim}^{+}-\mathrm{SCX} 8$ systems. SCX8 can bring about small size aggregates (SM), which is not observed for SCX4. The fact that SCX8 induces association to SM only in the presence of $\mathrm{NaCl}$, indicates that not only geometric factors affect the SM stability. Increased ion concentration shields the electrostatic 
repulsion among like charges of the constituents. $\mathrm{Na}^{+}$binding to the negatively charged surface of SM substantially enhances the driving force of association.

$\mathrm{C}_{14} \mathrm{mim}^{+}$and $\mathrm{SCX} 4$ self-organize to $\mathrm{NP}$, whose formation is accompanied by significantly more negative enthalpy change compared to that of the corresponding process promoted by SCX8 (Figure 6). $\Delta \mathrm{H}$ of $\mathrm{C}_{14} \mathrm{mim}^{+}-\mathrm{SCX} 4 \mathrm{NP}$ formation is much less sensitive to $\mathrm{NaCl}$ concentration than that of $\mathrm{C}_{14} \mathrm{mim}^{+}-\mathrm{SCX} 8 \mathrm{NP}$ production. The increase of $\Delta \mathrm{H}$ for the formation of the latter NPs upon the rise of $\mathrm{NaCl}$ amount probably originates from the binding of $\mathrm{Na}^{+}$cations to the surface of $\mathrm{C}_{14} \mathrm{mim}^{+}-\mathrm{SCX} 8$ NPs. The smaller size of these NPs induces larger specific area leading to a higher number of loosely bound cations, therefore increasing $\Delta \mathrm{H}$. Gradual replacement of methylimidazolium cations on the surface of NPs via competitive binding of $\mathrm{Na}^{+}$may also occur. The assembly into $\mathrm{C}_{14} \mathrm{mim}^{+}-\mathrm{SCX} 8 \mathrm{NPs}$ is by $\sim 11 \mathrm{~kJ} \mathrm{~mol}^{-1}$ more endothermic in $50 \mathrm{mM} \mathrm{NaCl}$ solution at $278 \mathrm{~K}$ than in the case of NPs containing SCX4. Despite the considerable positive $\Delta \mathrm{H}, \mathrm{C}_{14} \mathrm{mim}^{+}-\mathrm{SCX} 8 \mathrm{NPs}$ are stable at high methylimidazolium surfactant:SCX8 molar ratios even in $50 \mathrm{mM} \mathrm{NaCl}$ solution. This indicates that the predominant entropic contribution $(\mathrm{T} \Delta \mathrm{S})$ to the driving force overcompensate the unfavorable enthalpic term. As a consequence of the positive $\Delta \mathrm{S}, \mathrm{NPs}$ are stabilized to a larger extent at high temperature. Thus, temperature rise causes transformation of SM into NP.

In the presence of $\mathrm{NaCl}, \mathrm{SMs}$ containing $\mathrm{SCX} 8$ becomes enthalpically more stable than NPs at all temperatures (Figure 6). $\Delta \mathrm{H}$ of SM formation is much smaller than that of traditional $\mathrm{C}_{14} \mathrm{mim}^{+} \mathrm{Br}^{-}$micelles. ${ }^{31}$ Binding of $\mathrm{C}_{14} \mathrm{mim}^{+}$to $\mathrm{SCX} 8$ very efficiently promotes $\mathrm{SM}$ formation in $50 \mathrm{mM} \mathrm{NaCl}$ solution. The cmc of $0.72 \mathrm{mM}$ for conventional $\mathrm{C}_{14} \mathrm{mim}^{+}$ micelle formation diminishes by a factor of 48 and 60 at $\left[\mathrm{C}_{14} \mathrm{mim}^{+}\right] /[\mathrm{SCX} 8]$ ratio of 2.0 and 5.9, respectively. The larger relative amount of methylimidazolium surfactant shifts the binding equilibrium towards complexation, facilitating thereby micelle formation at slightly 
lower concentration. The electrostatic interaction between the macrocycle and $\mathrm{C}_{14} \mathrm{mim}^{+}$ assists the self-assembly of the long alkyl chains into micelle by screening the repulsion among the cationic headgroups. The cac of $\mathrm{SM}(\sim 0.015 \mathrm{mM} \text { in } 50 \mathrm{mM} \mathrm{NaCl})^{31}$ does not alter when the smaller SCX6 cavitand associates with $\mathrm{C}_{14} \mathrm{mim}^{+}$, although about $4.5 \mathrm{~kJ} \mathrm{~mol}^{-1}$ more enthalpy gain is observed compared with the SCX8-promoted association into SM. In the latter case, more polar headgroup region was detected (vide supra) indicating less tightly packed SM. The substantial flexibility of SCX8 may contribute to the looser SM structure and the low exothermicity of its formation.

The negative molar heat capacity changes for $\mathrm{C}_{14} \mathrm{mim}^{+}$micelles and SMs (Table 1) generally arise from the release of water from the hydrophobic surface of the alkyl tail. The $\Delta \mathrm{C}_{\mathrm{p}}$ values for the SCX4- and SCX8-initiated associations into SM and NP hardly vary (Table 1) and closely resemble those found for the micellization of sodium tetradecyl sulfate $\left(-0.608 \mathrm{~kJ} \mathrm{~mol}^{-1} \mathrm{~K}^{-1}\right)$ and 1-tetradecyl-2-picolinium bromide $\left(-0.598 \mathrm{~kJ} \mathrm{~mol}^{-1} \mathrm{~K}^{-1}\right)^{40}$ because the nonpolar substituent was always a tetradecyl moiety. The similar $\Delta \mathrm{C}_{\mathrm{p}}$ values suggest that the changes in hydration and interactions within the hydrophilic headgroup domain exert only a minor effect on the temperature dependence of $\Delta \mathrm{H}$. Since desolvation of tetradecyl chains is the dominant factor, $\Delta \mathrm{C}_{\mathrm{p}}$ of $\mathrm{SM}$ and $\mathrm{NP}$ formations barely differ for $\mathrm{C}_{14} \mathrm{mim}^{+}$associations with $\mathrm{SCX} 4$ and SCX8. The parallel variation of $\Delta \mathrm{H}$ values with temperature (Figure 6B) hinders thermally induced interconversion between SM and NP. The increase of the entropy contribution $(\mathrm{T} \Delta \mathrm{S})$ to the driving force with temperature is responsible for thermally initiated $\mathrm{SM} \rightarrow \mathrm{NP}$ structural change. This behavior is entirely different from that of $\mathrm{C}_{14} \mathrm{mim}^{+}$-SCX6 associates whose temperature-tuneable reversible transformation between $\mathrm{SM}$ and NP is promoted by the steeper $\Delta \mathrm{H}$ temperature dependence of NP formation in $\mathrm{NaCl}$ solutions compared to that of $\mathrm{SM}^{31}$ The major peculiarity of $\mathrm{C}_{14} \mathrm{mim}^{+}-\mathrm{SCX} 6 \mathrm{NPs}$ is the substantial growth of their $\Delta \mathrm{C}_{\mathrm{p}}$ with $\mathrm{NaCl}$ concentration, which 
probably originates from the growth of particle diameter upon gradual addition of salt. In contrast, the size of NPs encompassing SCX4 or SCX8 is insensitive to $\mathrm{NaCl}$ concentration, and thus $\mathrm{NaCl}$ barely influences their $\Delta \mathrm{C}_{\mathrm{p}}$ values.

\section{CONCLUSIONS}

The variation of the cavity size of the macrocycle brings about completely different characteristics for the self-assembled nanoproducts of $\mathrm{C}_{14} \mathrm{mim}^{+}-\mathrm{SCXn}$ type supramolecular amphiphiles. SCX4 always promotes NP formation when the molar ratio of the components is in $1.0<\left[\mathrm{C}_{14} \mathrm{mim}^{+}\right] /[\mathrm{SCX} 4]<4.6$ range. $\mathrm{NaCl}$ addition cannot induce transformation into SM because it leads to enthalpically more favorable association into NP. In contrast, the selforganization of $\mathrm{C}_{14} \mathrm{mim}^{+}$and SCX8 into NP becomes fairly endothermic in the presence of salt, and these components produce SMs in exothermic process. The cac of SMs barely alters when SCX8 cavitand is replaced with SCX6, but the local polarity of the interface can be tuned by the change of macrocycle size. The molar heat capacity changes for $\mathrm{C}_{14} \mathrm{mim}^{+}-\mathrm{SCXn}$ type NP and SM formations are very similar and resemble those reported for $\mathrm{C}_{14} \mathrm{mim}^{+}$halide micelles indicating the small contribution arising from the interactions in the headgroup domain. The only exception is $\mathrm{C}_{14} \mathrm{mim}^{+}-\mathrm{SCX} 6 \mathrm{NP}$ in $\mathrm{NaCl}$ solutions where the

increase of electrolyte concentration leads to NP diameter growth rendering thereby $\Delta \mathrm{C}_{\mathrm{p}}$ more negative. The results of the present work may find application in the rational design of tailor-made supramolecular surfactants and stimuli-responsive systems.

\section{Supporting Information}

Alteration of particle diameter as a function of temperature at $\left[\mathrm{C}_{14} \mathrm{mim}^{+}\right] /[\mathrm{SCX} 8]=4.9$ mixing ratio in the presence of 30 and $50 \mathrm{mM} \mathrm{NaCl}$. Enthalpy change upon titration of 0.1 mM SCX4 by $2.9 \mathrm{mM} \mathrm{C}_{14} \mathrm{mim}^{+}$in neutral aqueous solutions at various temperatures. Results 
of isothermal calorimetric titration of $0.1 \mathrm{mM} \mathrm{SCX8}$ with $5.54 \mathrm{mM} \mathrm{C}_{14} \mathrm{mim}^{+} \mathrm{Br}^{-}$aqueous solution at $\mathrm{pH} 7$ and various temperatures. Fluorescence intensity for saturated HONR solution as a function of $\mathrm{C}_{14} \mathrm{mim}^{+}$concentration in the presence of SCX8 and $50 \mathrm{mM} \mathrm{NaCl}$ at pH 7. The Supporting Information is available free of charge on the ACS Publications website at DOI:

\section{Acknowledgment}

We appreciate the support of this work by the Hungarian Scientific Research Fund (OTKA, Grant K104201) and the bilateral program between CNRS and the Hungarian Academy of Sciences. Z. M. thanks the support of the János Bolyai Research Scholarship of the Hungarian Academy of Sciences.

\section{REFERENCES}

(1) Yu, G.; Jie, K.; Huang, F. Supramolecular Amphiphiles Based on Host-Guest Molecular Recognition Motifs. Chem. Rev. 2015, 115, 7240-7303.

(2) Kang, Y.; Liu, K.; Zhang, X. Supra-Amphiphiles: A New Bridge between Colloidal Science and Supramolecular Chemistry. Langmuir 2014, 30, 5989-6001.

(3) Yao, X.; Wang, X.; Jiang, T.; Ma, X.; Tian, H. Bis-p-Sulfonatocalix[4]arene-Based Supramolecular Amphiphiles with an Emergent Lower Critical Solution Temperature Behavior in Aqueous Solution and Hydrogel. Langmuir 2015, 31, 13647-13654.

(4) Zhou, Q. B.; Wang, H.; Gao, T.; Yu, Y.; Ling, B. K.; Mao, L.; Zhang, H. B.; Meng, X. G.; Zhou, X. H. Supramolecular Vesicle: Triggered by Formation of Pseudorotaxane between Cucurbit[6]uril and Surfactant. Chem. Commun. 2011, 47, 11315-11317.

(5) Zhang, X.; Wang, C. Supramolecular Amphiphiles. Chem. Soc. Rev. 2011, 40, 94101. 
(6) Wang, C.; Wang, Z.; Zhang, X. Superamphiphiles as Building Blocks for Supramolecular Engineering: Towards Functional Materials and Surfaces. Small 2011, 7, $1379-1383$.

(7) Xing, P.; Sun, T.; Hao, A. Vesicles from Supramolecular Amphiphiles. RSC Adv. 2013, 3, 24776-24793.

(8) Guo, D.-S.; Liu, Y. Calixarene-Based Supramolecular Polymerization in Solution. Chem. Soc. Rev. 2012, 41, 5907-5921.

(9) Guo, D.-S.; Liu, Y. Supramolecular Chemistry of $p$-Sulfonatocalix[n]arenes and Its Biological Applications. Acc. Chem. Res. 2014, 47, 1925-1934.

(10) Basilio, N.; Francisco, V.; Garcia-Rio, L. Aggregation of $p$-SulfonatocalixareneBased Amphiphiles and Supra-Amphiphiles. International Journal of Molecular Sciences 2013, $14,3140-3157$.

(11) Liu, Y.-C.; Wang, Y.-Y.; Tian, H.-W.; Liu, Y.; Guo, D.-S. Fluorescent Nanoassemblies between Tetraphenylethenes and Sulfonatocalixarenes: A Systematic Study of Calixarene-Induced Aggregation. Organic Chemistry Frontiers 2016, 3, 53-61.

(12) Jiang, B.-P.; Guo, D.-S.; Liu, Y.-C.; Wang, K.-P.; Liu, Y. Photomodulated Fluorescence of Supramolecular Assemblies of Sulfonatocalixarenes and Tetraphenylethene. ACS Nano 2014, 8, 1609-1618.

(13) Megyesi, M.; Biczók, L. Considerable Change of Fluorescence Properties upon Multiple Binding of Coralyne to 4-Sulfonatocalixarenes. J. Phys. Chem. B 2010, 114, 28142819.

(14) Basilio, N.; Martín-Pastor, M.; García-Río, L. Insights into the Structure of the Supramolecular Amphiphile Formed by a Sulfonated Calix[6]arene and Alkyltrimethylammonium Surfactants. Langmuir 2012, 28, 6561-6568. 
(15) Lau, V.; Heyne, B. Calix[4]arene Sulfonate as a Template for Forming Fluorescent Thiazole Orange H-Aggregates. Chem. Commun. 2010, 46, 3595-3597.

(16) Basílio, N.; Piñeiro, Á.; Da Silva, J. P.; García-Río, L. Cooperative Assembly of Discrete Stacked Aggregates Driven by Supramolecular Host-Guest Complexation. J. Org. Chem. 2013, 78, 9113-9119.

(17) Guo, D.-S.; Jiang, B.-P.; Wang, X.; Liu, Y. Calixarene-Induced Aggregation of Perylene Bisimides. Org. Biomol. Chem. 2012, 10, 720-723.

(18) Wang, K.; Guo, D.-S.; Zhao, M.-Y.; Liu, Y. A Supramolecular Vesicle Based on the Complexation of $p$-Sulfonatocalixarene with Protamine and Its Trypsin-Triggered Controllable-Release Properties. Chem. Eur. J. 2016, 22, 1475-1483.

(19) Guo, D.-S.; Wang, K.; Wang, Y.-X.; Liu, Y. Cholinesterase-Responsive Supramolecular Vesicle. J. Am. Chem. Soc. 2012, 134, 10244-10250.

(20) Peng, S.; Gao, J.; Liu, Y.; Guo, D.-S. Facile Fabrication of Cross-Linked Vesicle via "Surface Clicking" of Calixarene-Based Supra-Amphiphiles. Chem. Commun. 2015, 51, $16557-16560$.

(21) Costa, C.; Francisco, V.; Silva, S. G.; do Vale, M. L. C.; García-Río, L.; Marques, E.

F. Supramolecular Self-Assembly between an Amino Acid-Based Surfactant and a Sulfonatocalixarene Driven by Electrostatic Interactions. Colloids Surfaces A: Physicochem. Eng. Aspects 2015, 480, 71-78.

(22) Peng, S.; Wang, K.; Guo, D.-S.; Liu, Y. Supramolecular Polymeric Vesicles Formed by $p$-Sulfonatocalix[4]arene and Chitosan with Multistimuli Responses. Soft Matter 2015, 11, 290-296.

(23) Qin, Z.; Guo, D. S.; Gao, X. N.; Liu, Y. Supra-Amphiphilic Aggregates Formed by pSulfonatocalix[4]arenes and the Antipsychotic Drug Chlorpromazine. Soft Matter 2014, 10, 2253-2263. 
(24) Francisco, V.; Basilio, N.; Garcia-Rio, L.; Leis, J. R.; Marques, E. F.; VazquezVazquez, C. Novel Catanionic Vesicles from Calixarene and Single-Chain Surfactant. Chem. Commun. 2010, 46, 6551-6553.

(25) Basilio, N.; Garcia-Rio, L. Sulfonated Calix[6]arene Host-Guest Complexes Induce Surfactant Self-Assembly. Chem. Eur. J. 2009, 15, 9315-9319.

(26) Basilio, N.; Gómez, B.; Garcia-Rio, L.; Francisco, V. Using Calixarenes to Model Polyelectrolyte Surfactant Nucleation Sites. Chem. Eur. J. 2013, 19, 4570-4576.

(27) Miskolczy, Z.; Biczók, L. Inclusion Complex Formation of Ionic Liquids with 4Sulfonatocalixarenes Studied by Competitive Binding of Berberine Alkaloid Fluorescent Probe. Chem. Phys. Lett. 2009, 477, 80-84.

(28) Wintgens, V.; Biczók, L.; Miskolczy, Z. Thermodynamics of Host-Guest Complexation between $p$-Sulfonatocalixarenes and 1-Alkyl-3-Methylimidazolium Type Ionic Liquids. Thermochim. Acta 2011, 523, 227-231.

(29) Wintgens, V.; Amiel, C.; Biczók, L.; Miskolczy, Z.; Megyesi, M. Host-Guest Interactions between 4-Sulfonatocalix[8]arene and 1-Alkyl-3-Methylimidazolium Type Ionic Liquids. Thermochim. Acta 2012, 548, 76-80.

(30) Wintgens, V.; Le Coeur, C.; Amiel, C.; Guigner, J. M.; Harangozó, J. G.; Miskolczy, Z.; Biczók, L. 4-Sulfonatocalix[6]arene-Induced Aggregation of Ionic Liquids. Langmuir 2013, 29, 7682-7688.

(31) Wintgens, V.; Miskolczy, Z.; Guigner, J. M.; Amiel, C.; Harangozó, J. G.; Biczók, L. Reversible Nanoparticle-Micelle Transformation of Ionic Liquid-Sulfonatocalix[6]arene Aggregates. Langmuir 2015, 31, 6655-6662.

(32) Vanyúr, R.; Biczók, L.; Miskolczy, Z. Micelle Formation of 1-Alkyl-3Methylimidazolium Bromide Ionic Liquids in Aqueous Solution. Colloids Surfaces A: Physicochem. Eng. Aspects 2007, 299, 256-261. 
(33) Yang, W.; Villiers, M. M. d. The Solubilization of the Poorly Water Soluble Drug Nifedipine by Water Soluble 4-Sulphonic Calix[n]arenes. Eur. J. Pharm. Biopharm. 2004, $58,629-636$.

(34) Suga, K.; Ohzono, T.; Negishi, M.; Deuchi, K.; Morita, Y. Effect of Various Cations on the Acidity of p-Sulfonatocalixarenes. Supramol. Sci. 1998, 5, 9-14.

(35) Paula, S.; Sues, W.; Tuchtenhagen, J.; Blume, A. Thermodynamics of Micelle Formation as a Function of Temperature: A High Sensitivity Titration Calorimetry Study. $J$. Phys. Chem. 1995, 99, 11742-11751.

(36) Galgano, P. D.; El Seoud, O. A. Surface Active Ionic Liquids: Study of the Micellar Properties of 1-(1-Alkyl)-3-Methylimidazolium Chlorides and Comparison with Structurally Related Surfactants. J. Colloid Interface Sci. 2011, 361, 186-194.

(37) Nagy, K.; Göktürk, S.; Biczók, L. Effect of Microenvironment on the Fluorescence of 2-Hydroxy-Substituted Nile Red Dye: A New Fluorescent Probe for the Study of Micelles. $J$. Phys. Chem. A 2003, 107, 8784-8790.

(38) Reichardt, C. Solvatochromic Dyes as Solvent Polarity Indicators. Chem. Rev. 1994, 94, 2319-2358.

(39) Israelachvili, J. N.; Mitchell, D. J.; Ninham, B. W. Theory of Self-Assembly of Hydrocarbon Amphiphiles into Micelles and Bilayers. Journal of the Chemical Society, Faraday Transactions 2: Molecular and Chemical Physics 1976, 72, 1525-1568.

(40) Muller, N. Temperature Dependence of Critical Micelle Concentrations and Heat Capacities of Micellization for Ionic Surfactants. Langmuir 1993, 9, 96-100. 


\section{Table of contents graphic}

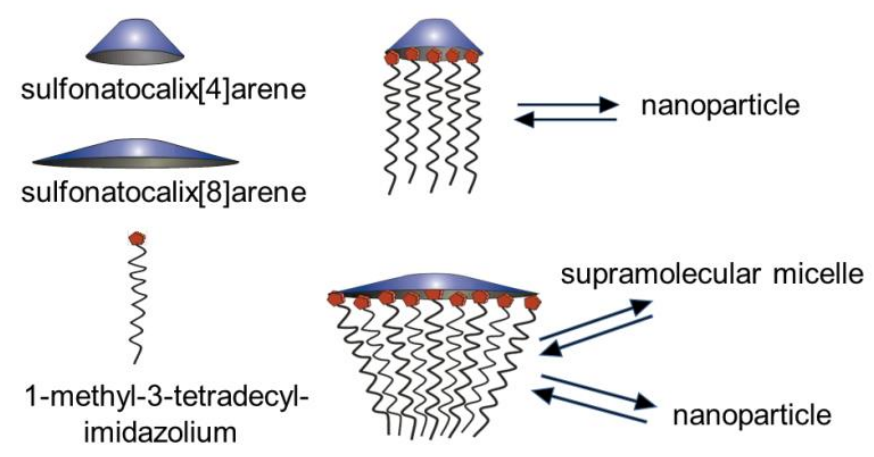

